\title{
Study on Chongqing Sports Industrial Structure and Disposition of Human Capital
}

\author{
Ming Yang1, Shunguang Yang2 ${ }^{2}$ Jindong Chang1,3* \\ ${ }^{1}$ College of Physical Education, Southwest University, Chongqing, China \\ ${ }^{2}$ Faulty of Education, Southwest University, Chongqing, China \\ ${ }^{3}$ Institute of Education Policy, Southwest University, Chongqing, China \\ Email: *hanglai@163.com
}

Received 11 May 2014; revised 26 June 2014; accepted 11 July 2014

Copyright (C) 2014 by authors and Scientific Research Publishing Inc.

This work is licensed under the Creative Commons Attribution International License (CC BY).

http://creativecommons.org/licenses/by/4.0/

(c) (7) Open Access

\begin{abstract}
There is a close relation between human capital and industrial structure. By discussing industrial structure and human capital of Chongqing sports, this paper attempts to explore the growth point for development of sports industry, the rational allocation between the industrial structure and human resources. The result shows that sports tourism industry, sports industry, sports lottery industry and leisure sports industry will become the optimal direction for the development of sports industry.
\end{abstract}

Keywords

Sports Industry, Industrial Structure, Distribution of Human Capital

\section{Introduction}

The development of sports industry is faced with both opportunities and challenges in the new period [1]. With the advancement of the idea of "Healthy City" proposed by the local government, we should seize the opportunity to intensify the reform of industrial structure, optimize the relations between industrial structure and human resources and coordinate the balanced development of Chongqing sports industry comprehensively.

\section{Human Capital Dispositions and Industrial Structure Optimization of Sports Industry}

China's sports industry started late, but the fast development in the coastal developed areas has formed a certain scale, such as in Beijing, Shanghai, Guangdong and other provinces, where the sports industry has begun to take *Corresponding author. 
shape [2]. Especially through the 2008 Beijing Olympic Games, Beijing sports events are operating rather maturely, and the industrial structure of capital allocation and the sports industry is relatively rational [3].

The industrial structure of a nation is manifested by certain structure of its production technologies [4], the advancement and alternation of which would cause the corresponding shifts in industrial structure [5]. Technological changes will lead to changes in industrial structure [6]; while the progress of science and technology will promote its changes, thus the industrial structure changes accordingly. With the implementation and development of China's western development strategy, upgrading the industrial structure of the western region is already around the corner [7]. Industry cannot develop without the intervention of human factors; human capital is the focus of industrial restructuring [8]. No matter how great the driving force of the scientific and technological progress on the industrial structure is, in essence it derives from the inventory and disposition of human capital. The direct reason of the formation and alternation of industrial structure of investment, and the fund reserves will possibly affect the restructuring of industrial structure [9]; the financial investment preference among different departments may be another influence factor [10]. Economic growth requires a reasonable allocation and co-adaptation of funds and manpower [11]. In essence, the reasonable economic growth process is the process in which two forms of capitals grow both in quantity and quality, i.e. the process of a reasonable allocation of human capital and funds [12].

As a new industry, sports industry will inevitably encounter manpower and capital these two different forms of resource allocation in the process of development. As an important western city of China's strategic development, an economic center of upper reaches of the Yangtze River, Chongqing has the necessity to allocate these two resources reasonably to promote the rapid development of its sports industry.

\section{The Current Situation of Chongqing Sports Industrial Structure and Human Resources}

Chongqing is still quite backward in fields of the economic and social development, sports infrastructure, sports and mass sports development (Table 1), the economic and social condition of production, circulation and consumption, etc, on which the sports industry survives and develops is still weak. Although the development of modern sports industry of Chongqing initiated in 1985, due to the relatively weak material basis for the development of sports industry, the long-term shortage of sports funding, the inadequate infrastructure investment (Table 2), as well as lagging awareness of public sports consumption (Table 3), by the end of 2007, the GDP

Table 1. Four municipalities’ economic and sport development indicators compared in 2007.

\begin{tabular}{ccccc}
\hline & GDP (Billion Yuan) & GDP per capita (Yuan) & $\begin{array}{c}11^{\text {th }} \text { Games gold medals } \\
\text { (Pieces/Rank) }\end{array}$ & $\begin{array}{c}11^{\text {th }} \text { Games total score } \\
\text { (score/Rank) }\end{array}$ \\
\hline Beijing & 9353.32 & 58,204 & $30 / 6$ & $1754 / 6$ \\
Shanghai & 12188.85 & 66,367 & $41 / 5$ & $2548.25 / 5$ \\
Tianjin & 5050.40 & 46,122 & $23 / 8$ & $867.5 / 11$ \\
Chongqing & 4122.51 & 14,660 & $2 / 28$ & $252.5 / 27$ \\
\hline
\end{tabular}

Table 2. 2003-2005 Chongqing sports funding and GDP Comparison.

\begin{tabular}{cccc}
\hline Year & 2003 & 2004 & 2005 \\
\hline Funding for sports (Billion Yuan) & 1.5237 & 1.8399 & 1.7698 \\
Chongqing GDP (Billion Yuan) & 2250.6 & 2691.5 & 3069.1 \\
Share (\%) & 0.0677 & 0.0684 & 0.0577 \\
\hline
\end{tabular}

Table 3. Chongqing public sports consumption survey Unit: Yuan.

\begin{tabular}{ccccccc}
\hline Consumer expenses & $<50$ & $50-100$ & $101-200$ & $201-300$ & $301-1000$ & $>1000$ \\
Share (\%) & 12.9 & 18.2 & 26.7 & 24.3 & 7.1 \\
Rank & 4 & 3 & 1 & 2 & 5 \\
\hline
\end{tabular}

Source: Zeng M. L. (2004) [15]. 
per capita of Chongqing is ¥14,622, the Engel Index of rural residents is $54.6 \%$, the Engel Index of urban residents is $37.0 \%$, and the output of the sports industry only accounts for $0.12 \%$ of the GNP [2]. This is significantly lower than the national average level of 1\%, ranked 22nd in the country [13]. Sports broadcast, naming rights and other intangible assets, tangible assets such as the development and use of space is insufficient, the public awareness of "spend money on health" is not still strong, the development of sports fields also remain on the primitive stage [14], the sports industry body has not developed sufficiently, besides Sports goods production and operation lack the scale and brand awareness.

By the end of 2007 [16], Chongqing has 3203 sports industry institutes, with an employment of 24,333 people, and a gross output value 1.177 billion Yuan, increased by 494 million Yuan, accounting for 0.12\% of the city’s GDP. Sports manufacturer are less than 20, the small number, limited scale, scattered layout, and also lacks of competitive large sports business industry groups at home and abroad. Sports lottery is a thriving sports industry in Chongqing, while its total annual sales is significantly lower (Table 4). Among sports industry practitioners, the educational structure is comprised of master or above, bachelor, junior college, high school and others these five levels (Table 5). In recent three years, the growth rate of sports business revenue is approximately more than $70 \%$ (Table 6).

From the data analysis, Chongqing is restricted by the economic base and development level of sports industry. Sports industry is still in developmental stage and the social and economic development are not coordinated. This was reflected in four aspects: First, the overall size is small. In 2007 sports revenues of the city accounted for only $0.12 \%$ of the city's GDP and $0.3 \%$ of the city's tertiary industry outputs; second, institutions are weak in strength. The structures of sports industry of Chongqing are mainly in forms of self-employed institutions, accounting for $\mathbf{8 5 . 3 \%}$ of the total number of city’s sports industry units, with only 142,800 Yuan per household in respect of the registered capital [17]; third, the industry is lagging behind. Sports insurance and other industries have not yet emerged. Sports advertising, sports agent and so on are just in the beginning, the scale is small and the social contribution is almost zero; Fourth, the productivity is low, social contribution is small, the total sports industry tax amounts to only 32,531,100 Yuan [18].

\section{Optimal Directions for Chongqing Sports Industries Development}

\subsection{Sports Tourism}

Sports tourism is a part of tourism industry, whose development is the prerequisite for the development of sports tourism. By the end of 2007, Chongqing has totally 43 national A-class tourist areas (spots), among which 17 AAAA-class tourism areas (spots), 6 AAA-class tourist areas (spots), 16 AA-class tourist areas (spots), and 4 A-class tourist areas (spots). The tourism of Chongqing has stepped onto the process of rapid development, which has laid a solid foundation for the development of its sports tourism [19].

Chongqing sports have a long history, as well as a profound foundation of sports tourism. Since ancient times,

Table 4. 2007 some provinces and cities sports lottery sales (Billion Yuan).

\begin{tabular}{cccccc}
\hline Year & Chongqing & Shanghai & Guangdong & Sichuan \\
\hline Amount & 3.68 & 8.36 & 30.01 & 15.62 & 9.74 \\
\hline
\end{tabular}

Table 5. Educational hierarchy of Chongqing sports industry employment.

\begin{tabular}{cccccc}
\hline Educational level & Master or above & Bachelor & Junior college & High school & Others \\
\hline Number & 14 & 379 & 406 & 7892 & 15642 \\
$\%$ & 0.06 & 1.56 & 1.67 & 32.43 & 64.28 \\
\hline
\end{tabular}

Table 6. 2005-2007 sports industry revenues in Chongqing compared (Billion Yuan).

\begin{tabular}{cccc}
\hline Year & 2005 & 2006 & 2007 \\
Sports industry revenues & 4.01 & 6.83 & 11.77 \\
Increasing rate (\%) & & 70.32 & 72.33 \\
\hline
\end{tabular}


martial arts, wrestling, game, the Dragon Boat, swim, mountain climbing, Dragon Dance and other folk sports had popularized in Ba \& Yu (another expression of Chongqing). Changshou District, Jiangbei District and Jiangjin District are famous for the name of "hometown of athletics" and "hometown of martial arts". Chongqing Municipal Bureau of Tourism has sponsored a public campaign of tourism with the theme of "enter the forest to embrace nature", private green voluntary associations had initiated activities such as "Hiking in Three Gorges” and etc., to develop physical fitness tourism market with the theme of fitness and entertainment, which are playing a significant role to promote and publicize the development of Chongqing sports and sports tourism resource exploitation. Chongqing is rich in national resources. At present, Chongqing Traditional sports have not been fully explored or sorted. We should actively encourage the exploration and sorting of traditional sports, in order to promote traditional sports programs and develop the traditional sports tourism. With its characteristics of appreciation and entertainment, and sports performance as a breakthrough, we can properly explore some participatory projects. If we can fully exploit the Traditional Ethnic Sports of huge potentiality in tourism, it will exert a very important effect in promoting the vigorous growth of the tourism market in Chongqing.

\subsection{Sports Events Industry}

Chongqing has always been popular with ball, football fans are almost crazy with the games, so that it has been presented on the screen, and plays an important role in the national football market. In 2003, Chongqing athletes participated in international and domestic competition and won once of the world champion, 23 times national champion. JIANSHE motorcycles chess team won five consecutive years the national chess champion. In 2006, Chongqing athletes participated in international and domestic competitions and won five times of world champion, 47 times' national champion. In 2007 Chongqing hosted more than 10 times national competitions [17]. From 2003 to 2005, she continuously and successfully held "Jialing Cup" cross-country motorcycle racing, and was honored as the "Motorcycle Capital of China".

Chongqing Datianwan stadium of light could accommodate 40,000 spectators. And the Yuan Jiagang sports center covering an area of 120,000 square meters ranks first in Western China; lots of golf courses, race course and other sports facilities in Chongqing have already been constructed or are under construction. Chongqing also has a JIANSHE motor chess team, ZONGSHEN motor team and a lot of first-class and even top sports teams of the nation. By holding competitions such as the World Cup boxing, Kickboxing Tournament, World Grand Prix, Amateur Football League, an amateur basketball league, the National Diving Championships and so on, as well as hosting football Asian Cup and a series of important games at home and abroad, Chongqing fosters its sports tourism market, and attracts many domestic and international tourists.

\subsection{Sports Lottery Industry}

Since in March 1994, the State Council approved issuing a nationwide sport lottery, Chongqing sports lottery had began to flourish. Sports lottery revenues were 184 million Yuan in 2002 [19], 229.6 million Yuan in 2005 [2], in 2007 it reached 368 million Yuan [17]. It increased rapidly and the development space is still available.

Sports Lottery is a highly self-entertained mass games and a good way to raise funds [20], from the perspective of Chongqing sports industry development, sports lottery industry outputs accounted for a great proportion. To vigorously develop the sports lottery and to make up realistic development policies, it will greatly enhance the development of sports industry in Chongqing.

\subsection{Leisure Sports Entertainment Industry}

Surveys indicated, the end of 2005, disposable income of Chongqing urban residents per capita is 10243.5 Yuan, increased by $10.2 \%$ compared with that of the last year, net income of rural residents per capita is 2809.3 Yuan, increased by $11.9 \%$. According to a investigation on the present situation of the sports consumption of Chongqing residents by Zeng M. L. (2004), among those residents who Consumes within 101 to 300 Yuan accounted for $51.0 \%$, whose sports consumption are above 1000 Yuan accounted for only $7.1 \%$, besides there were $31.1 \%$ people with sports consumption less than 100 Yuan or no sports consumption (Table 3). On the whole, the income of sports entertainment would gradually increase in proportion to the increase of income. At present, along with the proposition of constructing a "Healthy Chongqing", people's awareness of participating in sports and other entertainments gets much stronger, and the awareness of involving in exercising, sports consumption have 
gradually been recognized.

\section{Acknowledgements}

This research was supported by the Humanities and Social Science Research Youth Foundation of the Ministry of Education in China (Grant No.12YJC880005) and "the Fundamental Research Funds for the Central Universities (Grant No.SWU1309230)" and "the Fundamental Research Funds for the Central Universities (Grant No.SWU1309231)" and 2013 Annual National Social Science Fund Project "Social Support System rural integration of the education system" (Grant No.13ASH005) and the Research Project of Chongqing Sports Bureau (Grant No.B201417).

Corresponding author Chang Jin-dong is a lecturer in the College of Physical Education Southwest University, and a doctoral student of Education Statistics in the Mathematics and Statistics of Southwest University; e-mail: changlai@163.com. Here the authors would like to express heartfelt thanks.

\section{References}

[1] Bao, M.X. (2005) Formation and Development of Sports Industry in Foreign Countries [J]. Sports Science Research, 5, 001.

[2] Liang, J.P. and Chang, J.D. (2006) Study on Chongqing Sport Industry. The Research Report of the State Sports General Administration, 21-66.

[3] Owen, J.G. (2005) Estimating the Cost and Benefit of Hosting Olympic Games: What Can Beijing Expect from Its 2008 Games? Industrial Geographer, 3.

[4] Dasgupta, P. and Stiglitz, J. (1980) Industrial Structure and the Nature of Innovative Activity. The Economic Journal, 266-293. http://dx.doi.org/10.2307/2231788

[5] Peneder, M. (2003) Industrial Structure and Aggregate Growth. Structural change and economic dynamics, 14, 427448. http://dx.doi.org/10.1016/S0954-349X(02)00052-8

[6] Rowley, T., Behrens, D. and Krackhardt, D. (2000) Redundant Governance Structures: An Analysis of Structural and Relational Embeddedness in the Steel and Semiconductor Industries. Strategic Management Journal, 21, 369-386. http://dx.doi.org/10.1002/(SICI)1097-0266(200003)21:3<369::AID-SMJ93>3.0.CO;2-M

[7] Chen, X. (2007) A Tale of Two Regions in China Rapid Economic Development and Slow Industrial Upgrading in the Pearl River and the Yangtze River Deltas. International Journal of Comparative Sociology, 48, 167-201. http://dx.doi.org/10.1177/0020715207075399

[8] Storper, M. and Scott, A.J. (2009) Rethinking Human Capital, Creativity and Urban Growth. Journal of economic geography, 9, 147-167. http://dx.doi.org/10.1093/jeg/lbn052

[9] Audretsch, D.B., Carree, M.A., Van Stel, A.J. and Thurik, A.R. (2002) Impeded Industrial Restructuring: The Growth Penalty. Kyklos, 55, 81-98. http://dx.doi.org/10.1111/1467-6435.00178

[10] Chen, N.F. (1991) Financial Investment Opportunities and the Macroeconomy. The Journal of Finance, 46, $529-554$. http://dx.doi.org/10.1111/1467-6435.00178

[11] Barro, R.J. and Sala-i-Martin, X. (1990) Economic Growth and Convergence across the United States (No. w3419) National Bureau of Economic Research. http://dx.doi.org/10.3386/w3419

[12] Bodie, Z., Kane, A. and Marcus, A.J. (2011) Investments and Portfolio Management. McGraw-Hill/Irwin.

[13] National Bureau of Statistics (2008) China statistical Yearbook. China Statistics Press, 211-272.

[14] Chongqing Bureau of Statistics (2008) Chongqing Statistical Yearbook. China Statistics Press, 107-195.

[15] Zeng, M.L. (2004) A Survey on the Present Condition of Chongqing Residents Sports Consumption. Chongqing Technology and Business University (Natural Science), 2.

[16] Cao, F.H. and Zhao, D.P. (2009) Study of the Rapid Growth Point of Sports Industry in Chongqing. The Journal of Shandong Sport University, 4.

[17] Chen, S. (2009) The Blue Book of Chongqing: Report of Chongqing development in 2009. Chongqing Press, $211-237$.

[18] Lin, X.P., Yu, C.G. and Yang, Y. (2006) Study on the Present Situation and Strategies of China’s Sports Industry Development. Sports Science, 26, 36-42.

[19] Lu, X. (2004) Chongqing Sports Industry Ascertains. Chongqing Economic, 38-40.

[20] Chongqing Sports Bureau (2004) Sports Industry Research Report of Chongqing. 2-17. 
Scientific Research Publishing (SCIRP) is one of the largest Open Access journal publishers. It is currently publishing more than 200 open access, online, peer-reviewed journals covering a wide range of academic disciplines. SCIRP serves the worldwide academic communities and contributes to the progress and application of science with its publication.

Other selected journals from SCIRP are listed as below. Submit your manuscript to us via either submit@scirp.org or Online Submission Portal.
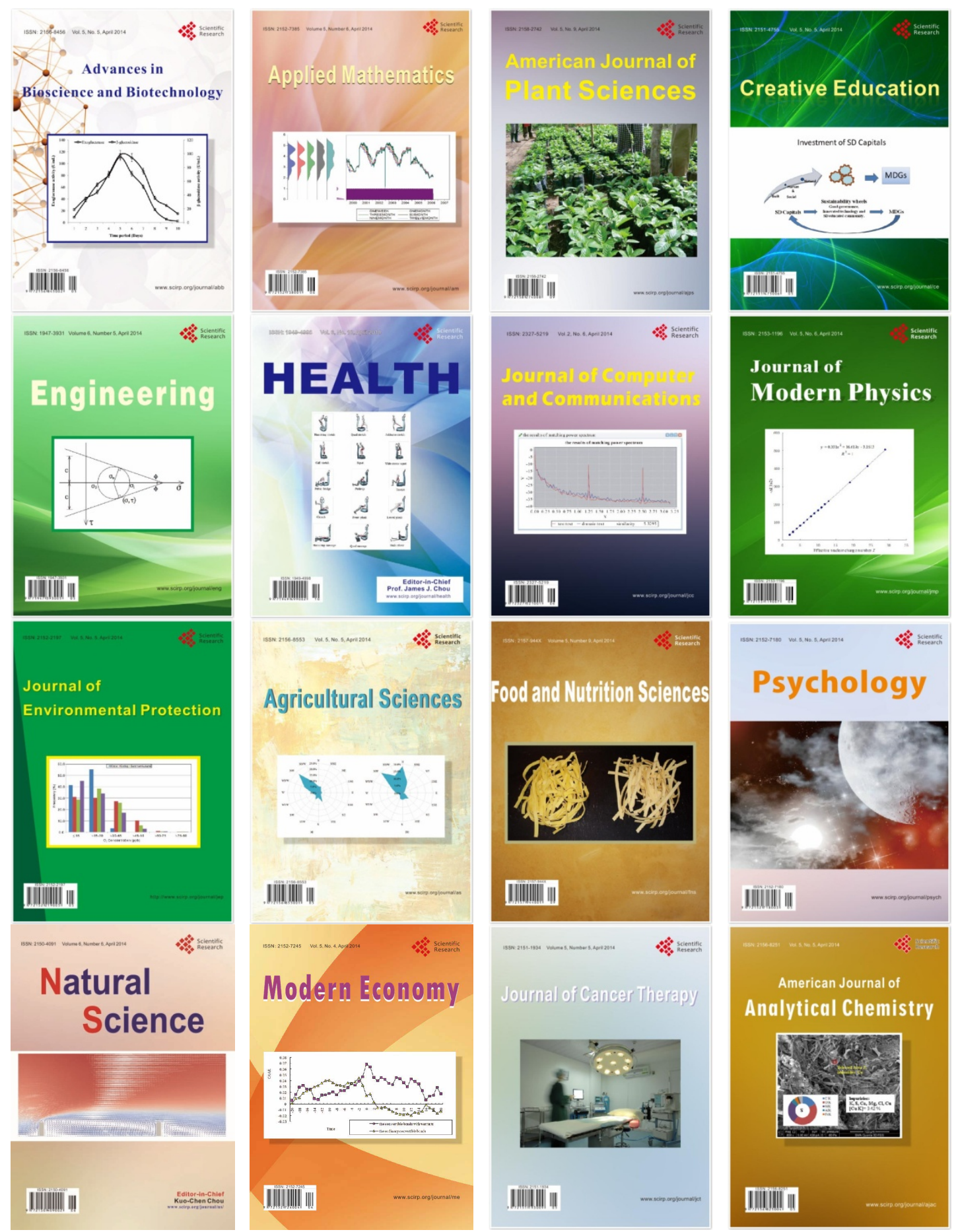